\title{
MICROSTRUCTURE EVOLUTION AND FRACTURE ANALYSIS OF HOT-ROLLED EXPLOSIVE-WELDED 06Cr13/Q345R COMPOSITES
}

\author{
RAZVOJ MIKROSTRUKTURE IN LOMNA ANALIZA KOMPOZITA, \\ NASTALEGA IZ EKSPLOZIJSKO ZVARJENIH MATERIALOV \\ 06Cr13 IN Q345R
}

\author{
Huaying Li, Guanghui Zhao*, Juan Li, Lifeng Ma, Qingxue Huang, Yugui Li \\ Coordinative Innovation Center of Taiyuan Heavy Machinery Equipment, Shanxi Provincial Key Laboratory of Metallurgical Device Design \\ Theory and Technology, Taiyuan University of Science and Technology, Taiyuan 030024, Shanxi, China
}

Prejem rokopisa - received: 2018-04-10; sprejem za objavo - accepted for publication: 2019-01-10

doi: $10.17222 /$ mit. 2018.073

\begin{abstract}
In this paper, with electron backscatter diffraction (EBSD) and SEM, the microstructure evolution and fractography of bonded interfaces were analyzed at various reduction rates $(0,15,30,40,50$ and 60$) \%$. A 06Cr13/Q345R explosive-welded composite interface of $50-80 \mu \mathrm{m}$ was the impact area of explosive cladding where the grains of $06 \mathrm{Cr} 13$ and Q345R were both low-sized and uniform. Subsequent to hot rolling, the explosive-welding effect on the 06Cr13-side interface was rapidly weakened. Compared to the $06 \mathrm{Cr} 13$-steel side, the explosive-cladding effect on the Q345R-side interface was slowly weakened. A continuous orientation distribution occurred, which indicated that a continuous, dynamic recrystallization mechanism existed in the explosive-welded composite plate. In contrast, the dominant recrystallization-deformation mechanism was the discontinuous, dynamic recrystallization, taking place under the rolling deformation. Two peaks existed between the $30-\%$ reduction rate and the $60-\%$ reduction rate, and they were apparently at positions $<15^{\circ}$ and $50^{\circ}-60^{\circ}$. As the rolling reduction rate increased, the two materials were significantly bonded together and the interface diffusion distances of the peaks and valleys decreased and tended to be homologous, whereas the composite interface fault was increasingly less apparent.

Keywords: 06Cr13/Q345R, rolling reduction, microstructure, fractography
\end{abstract}

Avtorji opisujejo raziskave razvoja mikrostrukture in fraktografijo na eksplozijsko zvarjenem spoju dveh materialov s pomočjo spektroskopije na osnovi difrakcije povratno sipanih elektronov (EBSD) in vrstičnega elektronskega mikroskopa (SEM). Razvoj mikrostrukture in fraktografija sta bila raziskana pri različnih stopnjah redukcije: $(0,15,30,40,50$ in 60$) \%$. Na eksplozijsko zvarjenem spoju dveh materialov (06Cr13 in Q345R) je nastala približno $50 \mu \mathrm{m}$ do $80 \mu \mathrm{m}$ mejna plast, znotraj katere so bila kristalna zrna obeh materialov - oboja majhna in enovita. Nadaljnje vroče valjanje kompozita je povzročilo hitro slabenje vpliva predhodnega medsebojnega eksplozijskega zvarjenja predvsem na strani 06Cr13. Primerjava strani, kjer se je nahajalo jeklo 06Cr13 s stranjo, kjer je bil Q345R, je pokazala, da je postopek vročega valjanja na to stran manj vplival. Nastopila je neprekinjena orientacija, kar kaže na to, da je prišlo do kontinuirne dinamične rekristalizacije v eksplozijsko vezani plošči. V nasprotju z dominantnim rekristalizacijskim deformacijskim mehanizmom je med vročim valjanjem prišlo do diskontinuirne dinamične rekristalizacije. Med $30 \%$ in $60 \%$ stopnjo redukcije sta bila dva maksimuma, ki sta se pojavila pri $<15^{\circ}$ in $50^{\circ}$ do $60^{\circ}$. Z večanjem stopnje deformacije med vročim valjanjem se je znatno krepila vez med obema materialoma in medmejne difuzijske razdalje obeh maksimumov in minimumov so se zmanjševale s tendenco homologacije, medtem ko so postajale napake na mejni ploskvi med obema materialoma vedno manj očitne (vidne).

Ključne besede: 06Cr13/Q345R, valjanje, stopnja redukcije, mikrostruktura, fraktografija

\section{INTRODUCTION}

In the past, a pressure-vessel composite plate was produced from a carbon-steel or low-alloy steel plate used as the base layer, whereas stainless-steel or nickelbased alloys were utilized as the cladding layer. Not only could this procedure ensure the strength of the matrix and the other mechanical properties, it also improved the material corrosion resistance..$^{1,2}$

At present, mainly three types of manufacturing methods for a pressure-vessel composite plate exist, including explosive welding, ${ }^{3,4}$ direct hot-rolling welding ${ }^{5,6}$ and explosive welding along with rolling. ${ }^{7}$ However, with explosive welding, the shockwave of the explosion

*Corresponding author e-mail:

zgh030024@163.com results in partial melting at the region of the bonding interface that quickly solidifies, which can easily cause solidification defects such as pores, cracks and shrinkage at the interface..$^{8,9}$ These defects severely affect the utilization of explosive panels, especially for high-temperature and high-pressure vessels. ${ }^{10}$

With the re-rolling technology, the interface defects of an explosive composite panel can be eliminated. Jiang Haitao et al. ${ }^{11}$ studied the microstructure and mechanical properties of $\mathrm{Ti}$ explosive composite panels subsequent to asymmetric rolling. Mamalis et al. ${ }^{12}$ fabricated an aluminum/copper bimetal composite plate with explosion and rolling, and also produced a nickel/titanium shapememory alloy bimetal strip. ${ }^{13} \mathrm{M}$. Asemabadi and M. Sedighi studied the effect of cold rolling on an $\mathrm{Al} / \mathrm{Cu}$ bimetal explosive clad plate. ${ }^{14}$ 


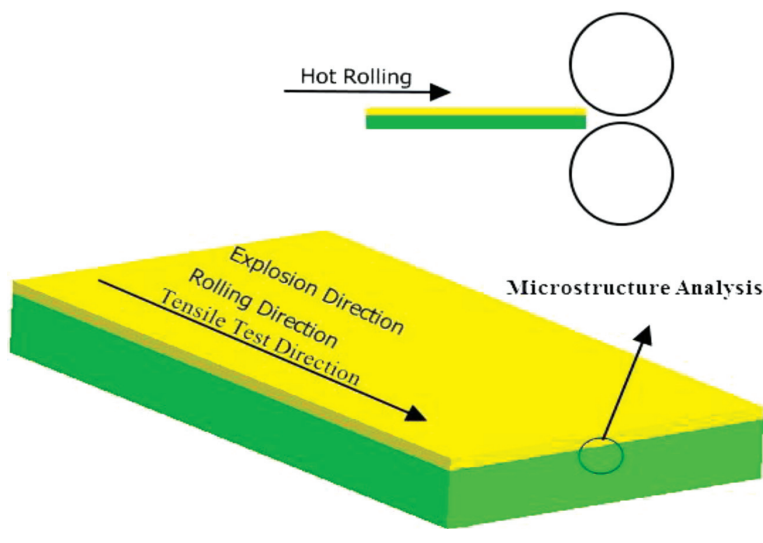

Figure 1: Schematic view of hot rolling

So far, re-rolling an explosive composite plate has been mainly focused on non-ferrous metal composite panels. Research on steel composite plates is rare. The effect of the rolling reduction on interface defects and interface recrystallization is not very clear.

In this paper, the interface microstructure of an explosion-welded and rolled 06Cr13/Q345R composite plate was analyzed, and the effect of the reduction ratio on the defects and recrystallization at the composite bonding interface was investigated.

\section{EXPERIMENTAL PART}

\subsection{Fabrication of a hot-rolled 06Cr13/Q345R explo- sive-welded composite}

In this study, a 06Cr13/Q345R explosive-welded composite was hot rolled. The thickness of the ferritic stainless steel $(06 \mathrm{Cr} 13)$ was $3 \mathrm{~mm}$ and the low-alloy steel thickness was $14 \mathrm{~mm}$. The chemical compositions of both $06 \mathrm{Cr} 13$ and Q345R are presented in Table $\mathbf{1 .}$
Table 1: Chemical compositions of $06 \mathrm{Cr} 13$ and Q345R (mass fractions)

\begin{tabular}{|c|c|c|c|c|c|c|}
\hline Alloy & $\mathrm{C}$ & $\mathrm{Si}$ & $\mathrm{Mn}$ & $\mathrm{P}$ & $\mathrm{S}$ & $\mathrm{Cr}$ \\
\hline 06Cr13 & 0.04 & 0.93 & 0.26 & 0.021 & 0.002 & 13.13 \\
\hline Q345R & 0.15 & 0.39 & 1.43 & 0.018 & 0.005 & - \\
\hline
\end{tabular}

Dimensions of the $06 \mathrm{Cr} 13 / \mathrm{Q} 345 \mathrm{R}$ explosive-welded samples were $17 \mathrm{~mm} \times 80 \mathrm{~mm} \times 150 \mathrm{~mm}$, being parallel to the explosion direction (Figure 1). The 06Cr13/ Q345R explosive-welded composite was preheated at $1250{ }^{\circ} \mathrm{C}$ and retained for $10 \mathrm{~min}$. Consequently, the hotrolling experiments were performed at $0.2 \mathrm{~m} / \mathrm{s}$, the stacks were roll-bonded at reduction rates of $(15,30,40$, 50 and 60$) \%$, and cooled down in air, subsequent to rolling.

\subsection{Microstructural analysis and mechanical-property tests}

The explosion-welded and rolled composites were polished and electro-etched in a solution of $10 \%$ of nitric acid and $90 \%$ of ethyl alcohol at an operating voltage of $20 \mathrm{~V}$. The TD-ND plane microstructure was observed with a scanning electron microscope (SEM) (ZIESS SIGMA FE-SEM) and detected with EBSD. The EBSD scan data was processed with the HKL Channel 5 software. This software analyzed the capability of IPF, misorientation, grain boundary angle and recrystallization. Through EDS, diffusion alloy elements at the bonding interface were investigated.

In order to evaluate the rolling-reduction effects on the tensile strength and tensile fracture morphology, the composite plates were prepared according to the Chinese Standard of GB/T6396-2008, along the rolling direction. For the study of the tensile-fracture type, tensile-fracture
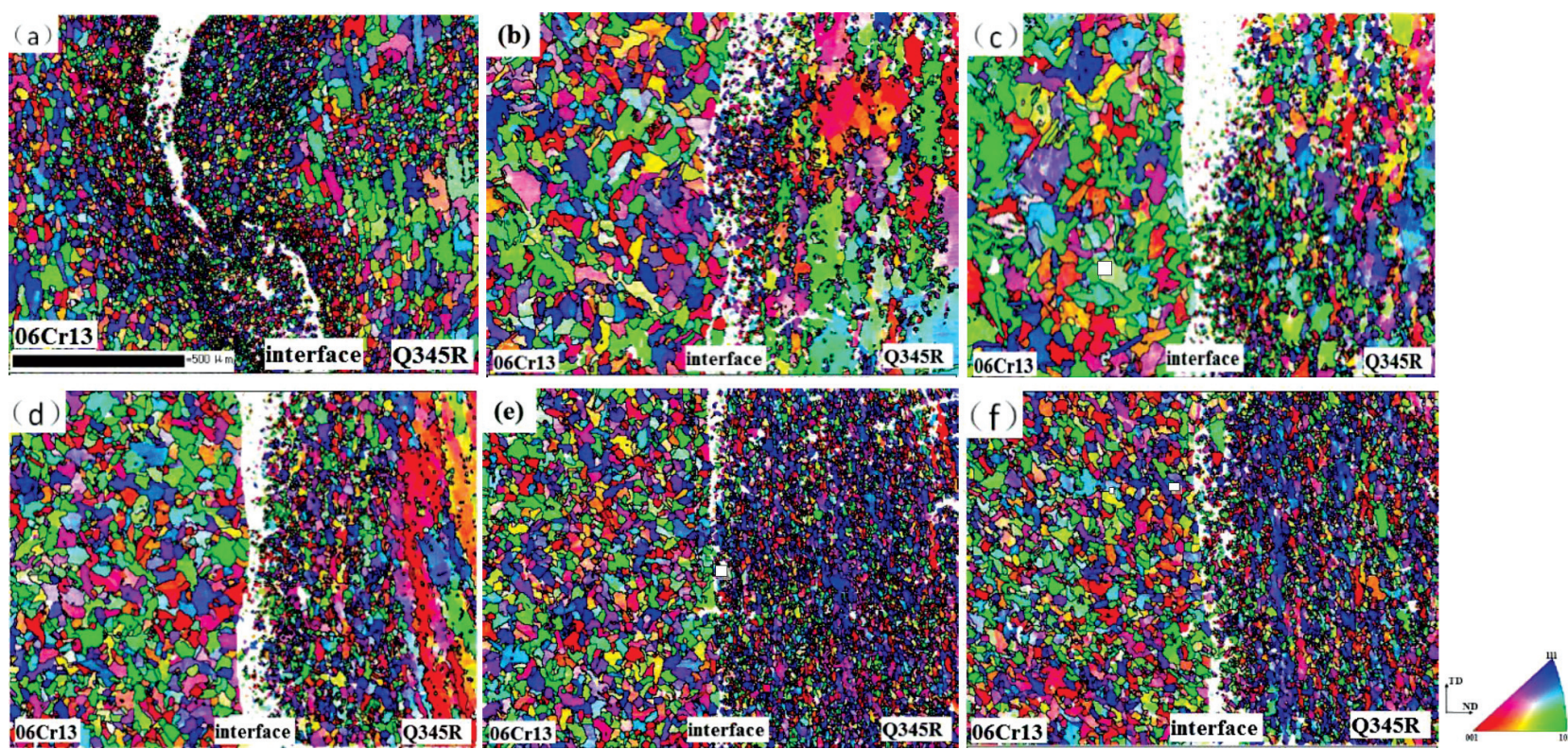

Figure 2: IPF maps of the 06Cr13/Q345R composite interface at various reduction rates: a) original explosion-clad plate, b) $15 \%$, c) $30 \%$, d) 40 $\%$, e) $50 \%$, f) $60 \%$ reduction rate 
surfaces were observed with a scanning electron microscope (SEM). Moreover, tensile-shear testing was conducted for the bonded interfaces of the samples.

\section{RESULTS AND DISCUSSION}

\subsection{Microstructural analysis}

The morphology of the TD-ND bonding interface was observed with EBSD and the microstructure evolution was analyzed for the 06Cr13/Q345R explosivewelded composites at various rolling reduction rates. The characteristics of the IPF map, the grain boundary size and the interface-area recrystallization of the hot-rolled, explosive-welded 06Cr13/Q345R composites were studied. Moreover, the formation mechanism of the hot-rolled, explosion-welded 06Cr13/Q345R composites was described.

Figure 2 presents the IPF maps of the $06 \mathrm{Cr} 13 /$ Q345R composite interface at various reduction rates that were selected from the TD-ND direction of the plane. The left-hand layer was made of the $06 \mathrm{Cr} 13$ steel, whereas the right-hand layer was made of the Q345R carbon steel. Between the two layers, there was a bonded interface. Figure 1a shows that the interface of the original explosion-welded plate was wavy, indicating that the two layers of the metal plates were completely joined by explosive cladding. The wavy joint region was caused by the explosive jet when $06 \mathrm{Cr} 13$ was ejected towards Q345R. Under periodic wave and shear stress, the thin metal layer on both sides of the interface had a strong plastic deformation, resulting in refined and uniform grains of both $06 \mathrm{Cr} 13$ and Q345R near the composite interface.
Near the interface, there was an explosive-welding impact area of 50-80 $\mu \mathrm{m}$ where the grains of $06 \mathrm{Cr} 13$ and Q345R were both low-sized and uniform. Subsequent to hot rolling, the explosive-welding effect on the $06 \mathrm{Cr} 13$ side was rapidly weakened. At the $15-\%$ reduction rate, the grains on the $06 \mathrm{Cr} 13$ side increased in size and the size was inhomogeneous, not demonstrating any effect of the explosive welding. As the rolling reduction rate increased, the stainless-steel grain size was uniform and refined. When the rolling reduction rate reached up to 50 $\%$, the $06 \mathrm{Cr} 13$ grains were uniform, fine and equiaxed, with no apparent preferred orientation. Compared to the 06Cr13 side, the explosive-cladding effect on the Q345R side interface was slowly weakened. At the 30-\% reduction rate, there were both low-sized and high-sized grains with a heavily mixed grain structure on the $\mathrm{Q} 345 \mathrm{R}$ side. When the reduction rate reached up to $40 \%$, the fine equiaxed grain structure tended to be uniform on the Q345R side. The grains on the side of the Q345R steel were uniform, fine and equiaxed, whereas most of the grains were oriented in the o plane at the $50-\%$ rolling reduction rate.

\subsection{Misorientation and misorientation angle distribu- tions}

Figure 3 presents the orientation of the $06 \mathrm{Cr} 13 /$ Q345R composite interface at various reduction rates. It was demonstrated that a continuous orientation distribution occurred, which indicated that a continuous dynamic recrystallization mechanism existed in the explosive-welded composite plate. In contrast, the dominant recrystallization deformation mechanism was disconti-
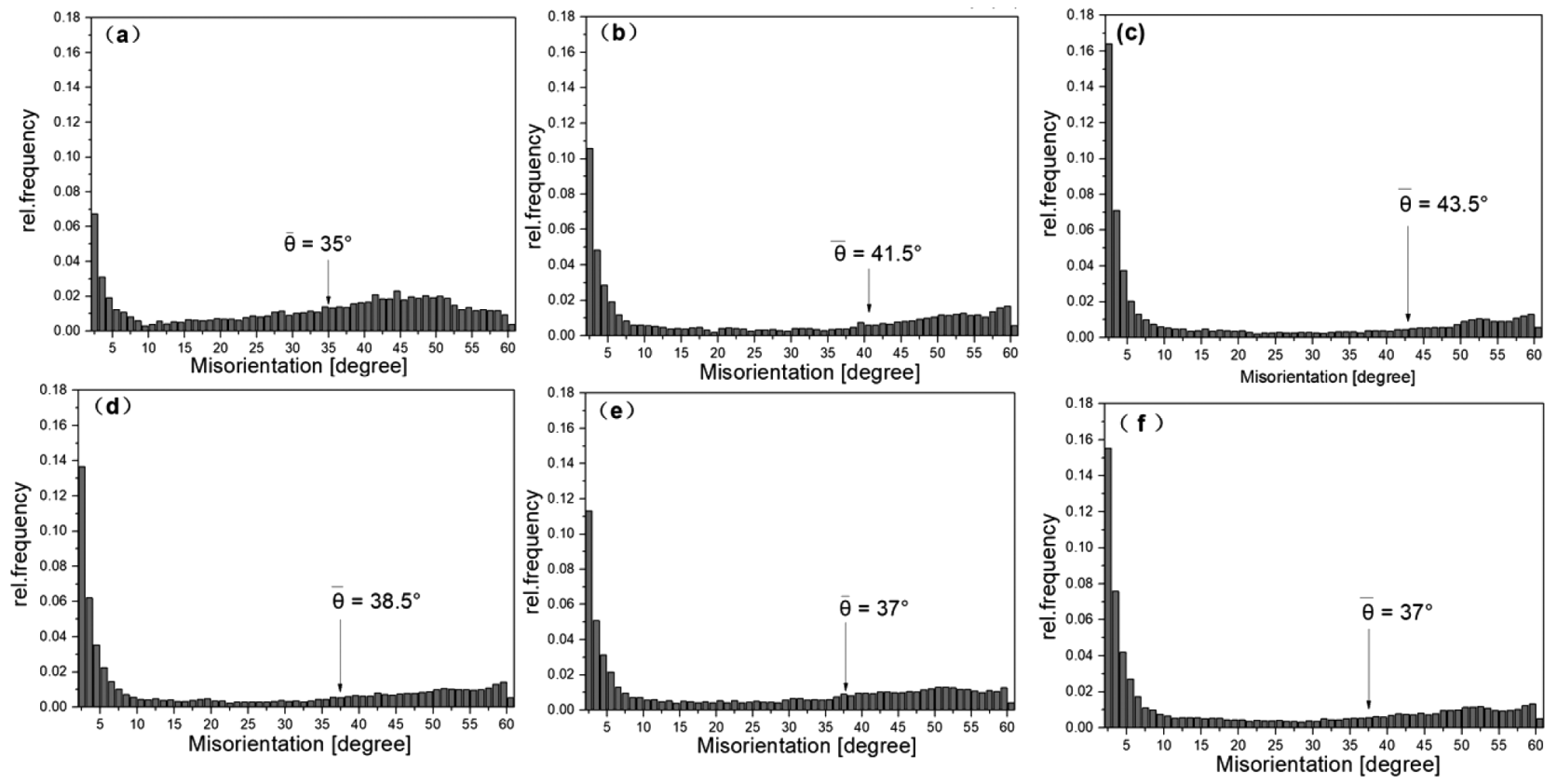

Figure 3: $06 \mathrm{Cr} 13 / \mathrm{Q} 345 \mathrm{R}$ composite-interface grain-boundary misorientation-distribution plots at various reduction rates: a) original explosive-clad plate, b) $15 \%$, c) $30 \%$, d) $40 \%$, e) $50 \%$, f) $60 \%$ 
nuous dynamic recrystallization under the rolling deformation. There were two peaks between the 30-\% reduction rate and $60-\%$ reduction rate, which were apparently at positions $<15^{\circ}$ and $50^{\circ}-60^{\circ}$.

The toughness of a material is closely related to the ratio of large-angle grain boundaries in the microstructure. ${ }^{15-17}$ The difference in the orientation angle of adjacent grain boundaries can determine the extension path of the microcracks in the material. When the microcrack extension encounters a large-angle grain boundary, it will deflect and hinder its rapid propagation, thus improving the crack propagation energy of the material. Generally, when a grain boundary with the phase difference angle greater than $15^{\circ}$ is the effective grain boundary, and the orientation difference angle is less than $15^{\circ}$, it can be considered that such a grain boundary has little effect on the crack propagation, but a small-angle grain boundary has substructure features that act as dislocation strengthening or grain-boundary strengthening due to dislocation entanglement. After rolling, a large number of small-angle grain boundaries generated at the interface of the composite plate help to improve the interfacial bonding strength of the composite plate through dislocation strengthening and grainboundary strengthening. This can be seen in the analysis of the shear; as the rolling progresses, the interface bonding strength increases.

Above all, the hot rolling contributed to the highangle misorientation and high-energy grain-boundary increase, which could improve the comprehensive mechanical properties of the composite plate.

\subsection{Recrystallization analysis}

Regarding the EBSD test results, the blue zones indicate the recrystallization and dislocation soft regions where the dislocation density is low; the yellow zones indicate the subgrain regions where the orientation difference is low; the red zones indicate high-deformation zones where the dislocation density is high. The three distinctions are the misorientation angles (2-7.5 degrees). The recrystallization/grain boundary map of the 06Cr13/Q345R composite interface at various reduction rates is presented in Figure 4. It is clear from Figure 4 that the degree of recrystallization in the original explosive-clad plate is high and the grains are low-sized. This is due to the fact that the plastic deformation zone was under high-speed detonation and shock during the explosive welding. Subsequently, low-sized recrystallized grains were formed during the normalizing process. When the rolling reduction rate was low, the recrystallization fraction was small and the sub-structure increased. The recrystallization fraction increased as the rolling reduction rate increased.

Figure 5 presents the recrystallization fraction of the 06Cr13/Q345R composite interface at various reduction rates. The recrystallization fraction of the original explosive composite reached $49.1 \%$. As the rolling reduction rate increased, the recrystallization fraction decreased. The recrystallization fraction at the rolling reduction rate of $30 \%$ was the lowest, $9.65 \%$. Subsequently, the recrystallization fraction increased. When the rolling reduction rate reached up to $50 \%$, the recrystallization fraction increased to $31.3 \%$. When the rolling reduction rate reached up to $60 \%$, the deformation grain
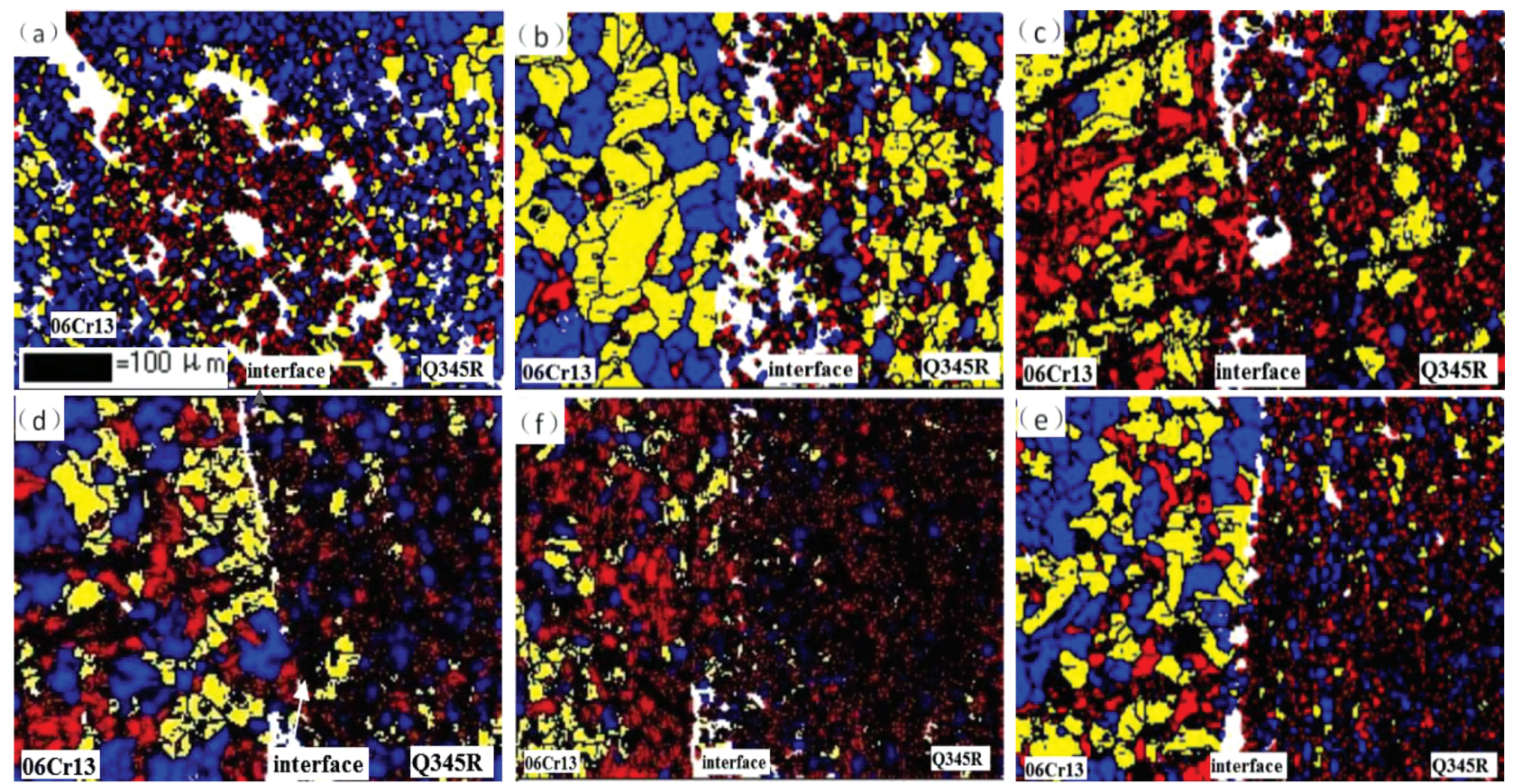

Figure 4: Recrystallization and grain-boundary diagram of the 06Cr13/Q345R composite interface at various reduction rates: a) original explosive-clad plate, b) $15 \%$, c) $30 \%$, d) $40 \%$, e) $50 \%$, f) $60 \%$ 


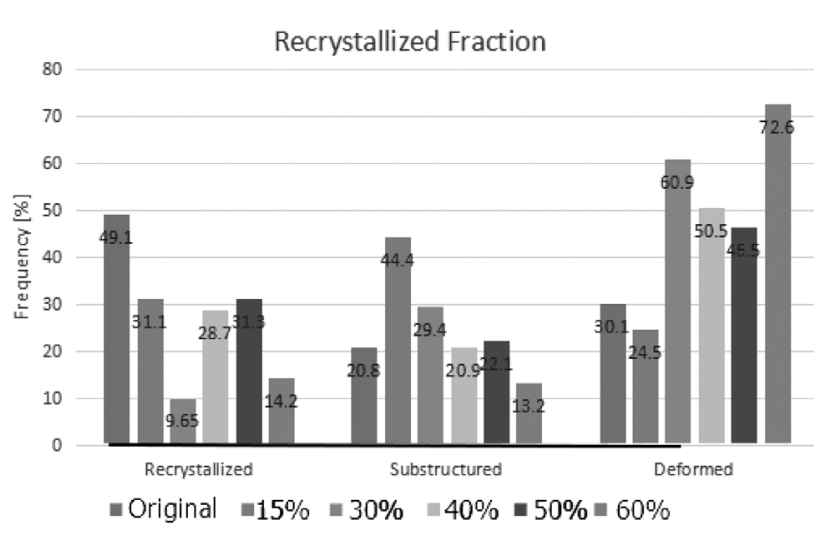

Figure 5: Recrystallization percentages for the 06Cr13/Q345R composite interface at various reduction rates

fraction was $72.6 \%$ due to the final rolling temperature decrease. The recrystallization of the composite interface facilitated the element diffusion within the interface and formed a strong metallurgical bond.

\subsection{Tensile/shear strength}

In accordance with the Chinese standard GB/T 6396-2008, tensile/shear testing was conducted for all the samples. Shear testing was conducted under the shear direction corresponding to the hot-rolling direction. If a fracture occurred within the bonded surface, it indicated that the tensile/shear strength of the bonded interface was lower than the strength of the explosive-welded materials. According to the observations of all the tensile/shear test samples (of both as fabricated and with different hot-rolling reductions), the fractures due to different hot-rolling reductions always occurred on the ferritic stainless-steel layer only, without a fracture occurrence at the joining interfaces, except for the explosive-welded sample. This indicated that the bonding strength was stronger compared to the $06 \mathrm{Cr} 13$ layer. As shown in Figure 6, the interface bonding strength exceeded $220 \mathrm{MPa}$ (Chinese standard GB/T 8165-2008). As the rolling reduction rate increased, the bonding strength increased. When the rolling reduction rate exceeded $50 \%$, the interfacial bonding strength increased slowly and the maximum bonding strength was 268.4 MPa.

Since the yield stress and ultimate-tensile strength of 06Cr13 were quite lower compared to Q345R, the former was easily broken. The original explosive-clad plate had a low bonding strength due to the interface having a melting zone as well as the effects of voids. ${ }^{10}$ The hotrolling treatment can homogenize and densify the microstructure, further improving the strength of the bonding interface for the explosively welded low-alloy steel/ ferritic stainless-steel plates. In the previous researches, no separation occurred at the joining interfaces. As an example, Durgutlu et al. ${ }^{18}$ demonstrated that no separation occurred at the interface of stainless steel and

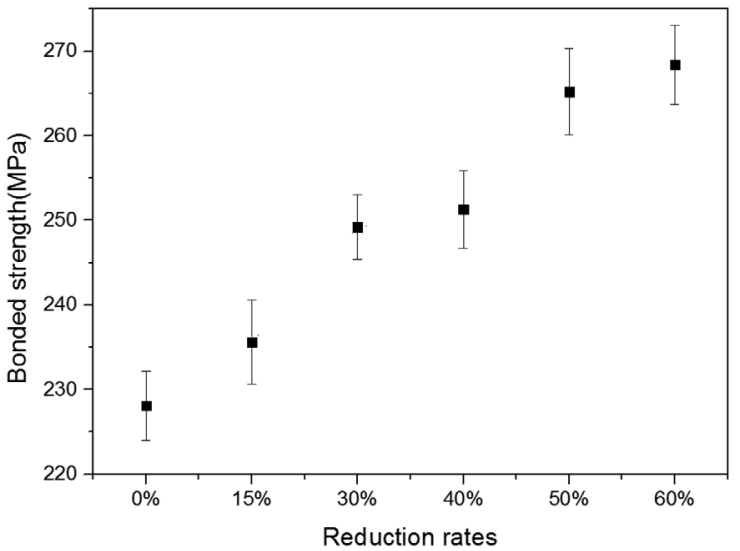

Figure 6: Bonding strength of the 06Cr13/Q345R composite at various reduction rates

copper multilayer plates. Also, M. Asemabadi and M. Sedighi ${ }^{14}$ reported that no separation occurred at the interface of aluminum and copper multilayer plates.

\subsection{Fractography}

The scanning electron microscope (SEM) was utilized to study the tensile-fracture morphology. The fracture morphologies of the $06 \mathrm{Cr} 13 / \mathrm{Q} 345 \mathrm{R}$ composite at various reduction rates are presented in Figure 7. The left-hand layer was made of the $06 \mathrm{Cr} 13$ steel, whereas the right-hand layer was made of the Q345R carbon steel. Between the two layers, a bonded interface was formed. According to Figure 7, no delamination appeared within the interface. This demonstrates that the bonded interface was firm.

Except for the $06 \mathrm{Cr} 13$ side of the original $06 \mathrm{Cr} 13 /$ Q345R composite, the metals in the other composite sustained ductile fracture. The fracture of the explosivewelded $06 \mathrm{Cr} 13$ steel was brittle with a wave structure (Figure 7a), caused by the explosive welding. As the rolling reduction rate increased, the two materials were significantly bonded together, while the composite interface fault was increasingly less apparent. The fracture surfaces of the composite interface were similar when the rolling reduction rate reached up to $50 \%$. The fracture surfaces exhibited a consistent low-sized and dense dimple, which indicated that the grains were further refined and that the composite interface was firmly combined.

The aforementioned fracture-surface analysis demonstrated that the hot-rolling treatment caused the microstructure of the $06 \mathrm{Cr} 13 / \mathrm{Q} 345 \mathrm{R}$ explosive-welded composite to become uniform and dense. Subsequent to hot rolling, the fracture in the 06Cr13/Q345R composite plate was ductile. In similar studies, ${ }^{9,11,14}$ such a situation was also reported. Hot rolling could cause a dense microstructure and reduce the defects, such as the melting zone on the composite interface of the 06Cr13/Q345R explosive-welded composite, further improving the 

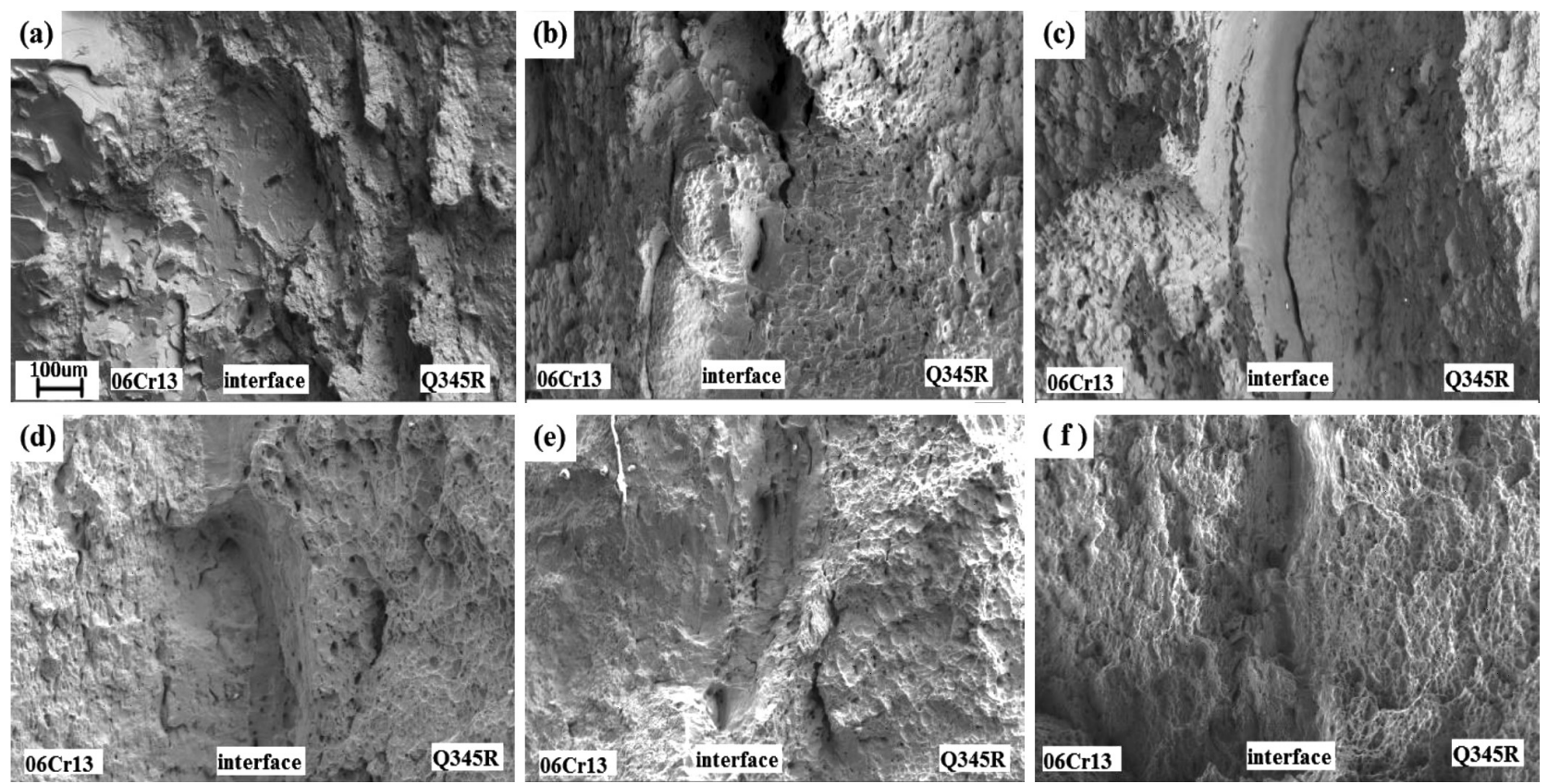

Figure 7: Fracture surface of the $06 \mathrm{Cr} 13 / \mathrm{Q} 345 \mathrm{R}$ composite at various reduction rates: a) original explosive-clad plate, b) $15 \%$, c) $30 \%$, d) $40 \%$, e) $50 \%$, f) $60 \%$

bonding strength of the $06 \mathrm{Cr} 13 / \mathrm{Q} 345 \mathrm{R}$ explosion-clad plate interface.

\section{CONCLUSIONS}

In this paper, the microstructure and tensile fracture of a 06Cr13/Q345R explosion-welded and rolled composite plate were studied:

1) The $06 \mathrm{Cr} 13 / \mathrm{Q} 345 \mathrm{R}$ explosion-welded composite interface of 50-80 $\mu \mathrm{m}$ was the impact area of explosive cladding where the grains of both $06 \mathrm{Cr} 13$ and Q345R were low-sized and uniform. Subsequent to hot rolling, the explosive-welding effect on the $06 \mathrm{Cr} 13$ side of the interface was rapidly weakened. Compared to the $06 \mathrm{Cr} 13$ steel side, the explosive-cladding effect on the Q345R side of the interface was slowly weakened. When the reduction rate reached up to $40 \%$, the fine, equiaxed grain structure tended to be uniform on the Q345R side where most of the grains were oriented in the o plane at the $50-\%$ rolling reduction rate.

2) A continuous-orientation distribution occurred, indicating that a continuous dynamic recrystallization mechanism existed in the explosive-welded composite plate. In contrast, the dominant recrystallization-deformation mechanism was discontinuous dynamic recrystallization under the rolling deformation. There were two peaks between the $30-\%$ reduction rate and $60-\%$ reduction rate, which were apparently at positions $<15^{\circ}$ and $50^{\circ}-60^{\circ}$.

3) The recrystallization fraction of the original explosive-welded composite amounted to $49.1 \%$. As the rolling reduction rate increased, the recrystallization fraction decreased. The recrystallization fraction at the rolling reduction rate of $30 \%$ was the lowest, $9.65 \%$. Later, the recrystallization fraction increased. When the rolling reduction rate reached up to $50 \%$, the recrystallization fraction increased to $31.3 \%$. When the rolling reduction rate reached up to $60 \%$, the deformation-grain fraction was $72.6 \%$ due to the final rolling temperature decrease.

4) The hot-rolling treatment can improve the strength of the bonding interface of the explosive-welded plates. When the rolling reduction rate exceeded $50 \%$, the interfacial bonding strength increased slowly and the maximum bonding strength was $268.4 \mathrm{MPa}$. As the rolling reduction rate increased, the two materials were significantly bonded together, while the composite-interface fault was increasingly less apparent. The fracture surfaces of the composite interface were similar when the rolling reduction rate reached up to $50 \%$.

\section{Acknowledgments}

This project was supported by the Coal Based and Low Carbon Joint Funds of Shanxi (U1510131), the Key Research and Development Program of the Shanxi Province (201603D111004 and 201703D111003), the Science and Technology Major Project of the Shanxi Province (MC2016-01) as well as the Coordinative Innovation Center of Taiyuan Heavy Machinery Equipment.

\section{REFERENCES}

${ }^{1}$ F. Fehim, Recent developments in explosive welding, Mater. Design, 32 (2011), 1081, doi:10.1016/j.matdes.2010.10.017 
${ }^{2}$ P. Manikandana, K. Hokamotob, M. Fujitac, K. Raghukandan, R.Tomoshige, Control of energetic conditions by employing interlayer of different thickness for explosive welding of titanium/304 stainless steel, J Mater Process Tech, 195 (2008), 232, doi:10.1016/ j.jmatprotec.2007.05.002

${ }^{3}$ M. S. A. A. Akbari, S. P. Farhadi, Experimental investigation of explosive welding of cp-titanium/AISI 304 stainless steel, Mater. Design, 30 (2009), 459, doi:10.1016/j.matdes.2008.06.016

${ }^{4}$ J. Songa, A. Kostkaa, M. Veehmayerb, D. Raabea, Hierarchical microstructure of explosive joints: Example of titanium to stee cladding, Mat Sci Eng A, 528 (2011), 2641, doi:10.1016/j.msea. 2010.11.092

${ }^{5}$ J. C. Yan, D. S. Zhao, C. W. Wang, L. Y. Wang, Y. Wang \& S. Q. Yang, Vacuum hot roll bonding of titanium alloy and stainless steel using nickel interlayer, Mater Sci Tech-Lond, 25 (2009), 914-918, doi:10.1179/174328408X365766

${ }^{6}$ D. S. Zhao, J. C. Yan, Y. Wang, S. Q. Yang, Relative slipping of interface of titanium alloy to stainless steel during vacuum hot roll bonding, Mat Sci Eng A, 499 (2009), 282, doi:10.1016/j.msea. 2007.11.112

${ }^{7}$ Z. Yuanmou, Rolling of explosive welded Ni-stainless steel composite sheet, J Iron Steel Res, 3 (1991) 4, 27-33

${ }^{8}$ J. Songa, A. Kostkaa, M. Veehmayerb, D. Raabea, Hierarchical microstructure of explosive joints: Example of titanium to steel cladding, Mat Sci Eng A, 528 (2011) 6, 2641-2647, doi:10.1016/ j.msea.2010.11.092

${ }^{9}$ C. Yu, H. Xiao, H. Yu, Z. C. Qi, C. Xu, Mechanical properties and interfacial structure of hot-roll bonding TA2/Q235B plate using DT4 interlayer, Mat Sci Eng A, (2017), doi:10.1016/j.msea.2017.03.118

${ }^{10}$ G. Zhao, Q. Huang, C. Zhou, X. Yang, G. Liu, L. Ma, Investigation of hot rolling influence on the explosive-welded clad plate, Mater Scit, 22 (2016) 4, doi:10.5755/j01.ms.22.4.12409
${ }^{11}$ J. Haitao, Y. Xiaoqian, L. Jixiong, D. Xiaoge, Z. Shangwu, Influence of asymmetric rolling parameters on the micro-structure and mechanical properties of titanium explosive clad plate, Rare Metal Mat Eng, 43 (2014) 11, 2631, doi:10.1016/S1875-5372(15)60016-9

${ }^{12}$ A. G. Mamalis, N. M. Vaxevanidis, A. Szalay, J. Prohaszka, Fabrication of aluminium/copper bimetallics by explosive cladding and rolling, Mater. Process. Technol., 44 (1994), 99-117, doi:10.1016/ 0924-0136(94)90042-6

${ }^{13}$ A. G. Mamalis, A. Szalay, N. M. Vaxevanidis, D. I. Pantelis, Macroscopic and microscopic phenomena of nickel/titanium "shapememory" bimetallic strips fabricated by explosive cladding and rolling, Mat Sci Eng A, 188 (1994), 267-275, doi:10.1016/09215093(94)90381-6

${ }^{14}$ M. Asemabadi, M. Sedighi, M. Honarpisheh, Investigation of cold rolling influence on the mechanical properties of explosive-welded Al/Cu bimetal, Mat Sci Eng A, 558 (2012), 144-149, doi:10.1016/ j.msea.2012.07.102

${ }^{15}$ B. Hwang, Y. G. Kim, S. Lee, Y. M. Kim, N. J. Kim, J. Y. Yoo, Effective grain size and charpy impact properties of high-toughness X70 pipeline steels, Metall Mater Trans A, 36 (2005) 8, 2107-2114, doi:10.1007/s11661-005-0331-9

${ }^{16}$ W. T. Huo, J. T. Shi, L. G. Hou, J. S. Zhang, An improved thermomechanical treatment of high-strength $\mathrm{Al}-\mathrm{Zn}-\mathrm{Mg}-\mathrm{Cu}$ alloy for effective grain refinement and ductility modification, J Mater Process Tech, 239 (2017), 303-314, doi: 10.1016/j.jmatprotec.2016.08.027

${ }^{17}$ H. Zhao, B. P. Wynne, E. J. Palmiere, Effect of austenite grain size on the bainitic ferrite morphology and grain refinement of a pipeline steel after continuous cooling, Mater Charact, 123 (2017), 128-136, doi:10.1016/j.matchar.2016.11.025

${ }^{18}$ A. Durgutlu, B. Gulenc, F. Findik, Examination of copper/stainless steel joints formed by explosive welding, Mater Design, 26 (2005), 497-507, doi:10.1016/j.matdes.2004.07.021 